\title{
Foreign Direct Investment and Economic Growth in the Arab Region: The Case of Knowledge Spillover Effects
}

\author{
Nayef Al-Shammari ${ }^{1} \&$ Huda Al-Rashid ${ }^{1}$ \\ ${ }^{1}$ Department of Economics, College of Business Administration, Kuwait University, Kuwait \\ Correspondence: Nayef Al-Shammari, Department of Economics, College of Business Administration, Kuwait \\ University, Kuwait. E-mail: alshammari@cba.edu.kw or alshammari2000@gmail.com
}

Received: May 11, 2016

Accepted: June 27, 2016

Online Published: December 14, 2016

doi:10.5539/ijef.v9n1p106

URL: http://dx.doi.org/10.5539/ijef.v9n1p106

\begin{abstract}
This research aims to focus on how institutional barriers in the Arab region may account for losses in FDI inflows along with their potential technology spillover effects, as well as to show how the deficiency of absorptive capacities serve as an important factor for attracting inflows. The analysis relies on endogenous growth models at an aggregate regional level and a microeconomic firm-level. Findings based on linear OLS regressions, reveal a positive correlation between improved institutional factors and potential FDI spillovers, with significance varying in certain countries. Policy implications involve having targeted FDI policies to enhance absorptive capacities, improving information asymmetry to reduce corruption, and enhancing the labor market regulatory framework to improve human capital development as an incentive for FDI inflows.
\end{abstract}

Keywords: economic growth, endogenous growth theories, foreign direct investment, spillovers

\section{Introduction}

Foreign direct investment is key contributor to economic growth, both explicitly and implicitly. Investment is a major factor to boost economic growth, however, with FDIs also lead to positive externalities that additionally increase growth levels through their technology spillover effects. When FDIs flow inwards towards a host economy, they also transmit their knowledge and technology; for example, the presence of US-based transnational corporations like Apple Inc. in its manufacturing bases not only adds to the economic growth of the host country by increasing the cumulative gross domestic product (by increasing production and sales), but also boosts economic development by transmitting the technology associated with its products and by providing extensive training to local employees.

This therefore boosts GDP levels as well as human capital development, and may induce further local innovation. These externalities (that the literature most often refers to as "spillovers") emphasize the importance of giving enough recognition to the potential of FDIs as sources of economic growth. This research investigates how institutional factors in the Arab region may act as a hindrance towards FDI spillovers from reaching their full potential. In order to do that, we must first ask, what is the current state of foreign investment in the Arab region? Figure 1, illustrates a recent decline in FDI levels in the Arab region especially after the 2008 economic crisis. The trend is continuously declining and clearly illustrates the detrimental aftermath of the global crisis on the investment levels as a whole. However, it is important to examine whether FDI levels are low because of the recession or due to other factors? Figure 2 illustrates a trend comparison between the Arab region and other developed economies such as the United States and United Kingdom, the European Union, and other high-income economic groups. 


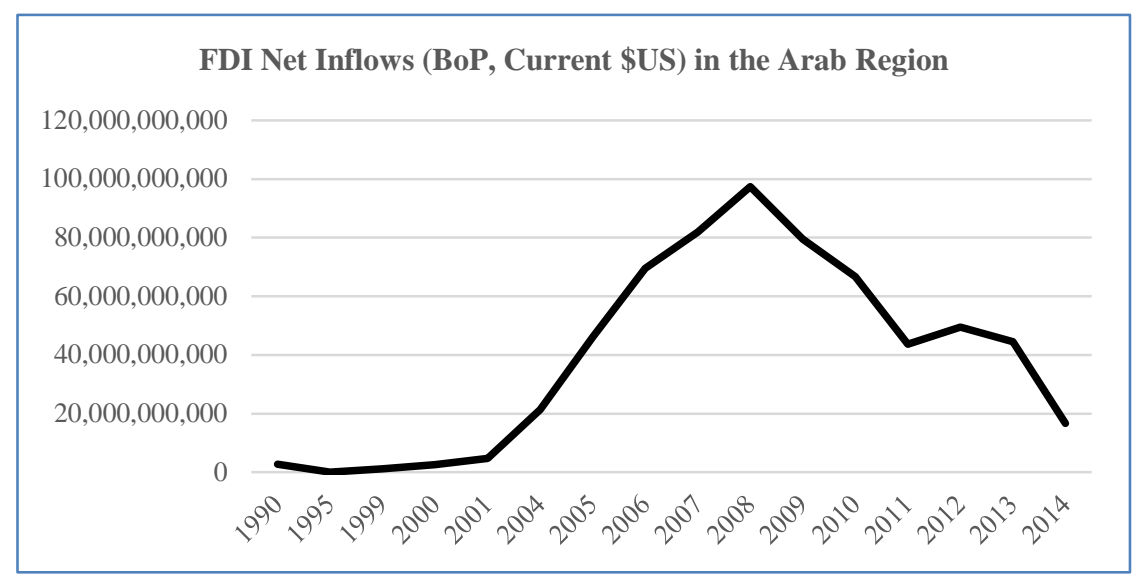

Figure 1. FDI net inflows in the Arab world 1990-2014 (World development indicators, 2015)

The trend line is consistent with FDIs in the Arab region, whereby inflows have decline severely after the 2008 crisis. However, high income OECD countries and the European Union have a substantially larger amount of FDI inflows than the Arab region. It is true that other advanced economies such as the US and UK have similar low levels of inflows, but trend lines in the Arab world seem to have an overall lower level than other economic "groups" such as the high income OECD countries as a whole. Thus, the decline in FDI inflows in the region are most likely due to the effects of the economic recession, as in the trend lines in other economic groups, however, there must be an explanation underlying the overall amount or stock of inflows, that is substantially lower than that of high income OECD countries; this highlights the topic of focus, which is to look at the institutional framework as a major underlying determinant of FDI inflows.

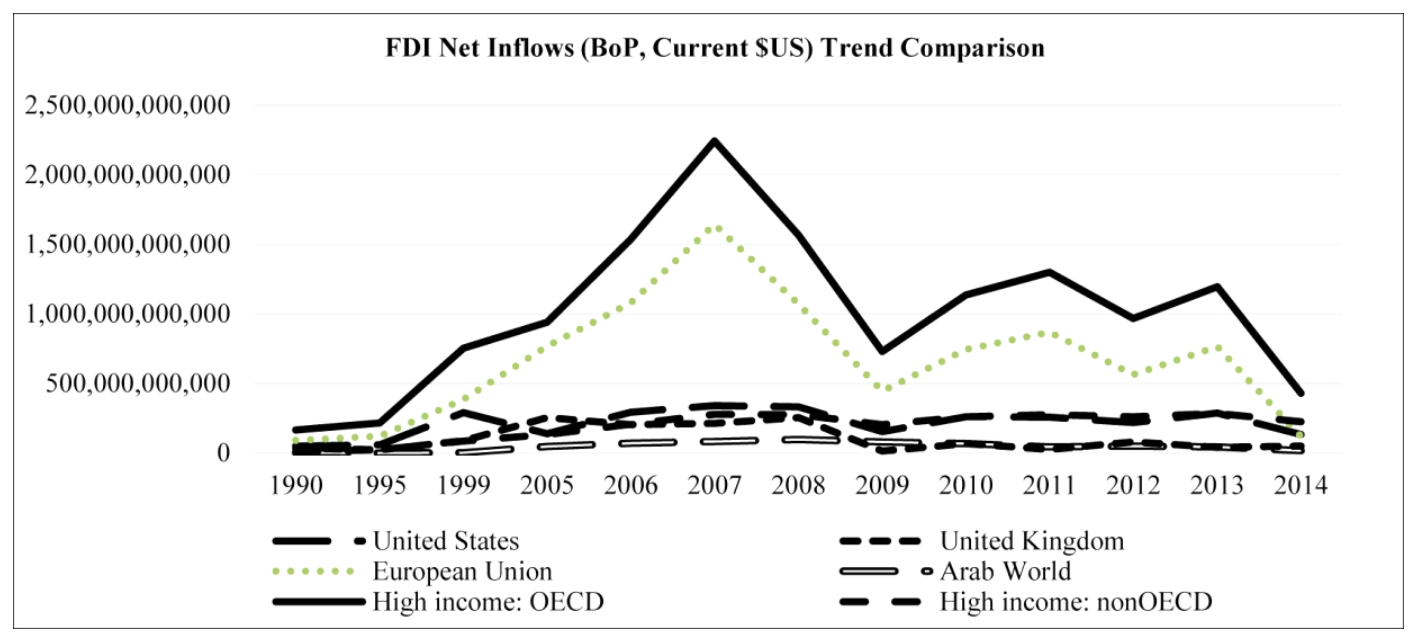

Figure 2. FDI net inflows trend comparison 1990-2014 (World development indicators 2015)

Specifically, the investment climate acts as an important indicator got the institutional framework in the region; Figure 3 illustrates the "ease of doing business" in different Arab countries, while comparing the overall trend in the region with more advanced economies (Note 1). The data indicates that in most Arab countries, the procedures to conduct business is often very difficult; some countries are better off than others such as the UAE, Bahrain and Qatar. However, when comparing even the most effective Arab countries in terms of doing business, the data still falls short when looking at developed economies such as the US, UK, Germany and Singapore with a perfect score of 1 indicating a perfectly easy environment for business startups. Thus, although the overall trend in the region is quite low, it is important to look at a sample of firms from each country, to account for differences within the region, which is what the microeconomic firm-level analysis aims to examine the business environments for a selection of Arab countries. 


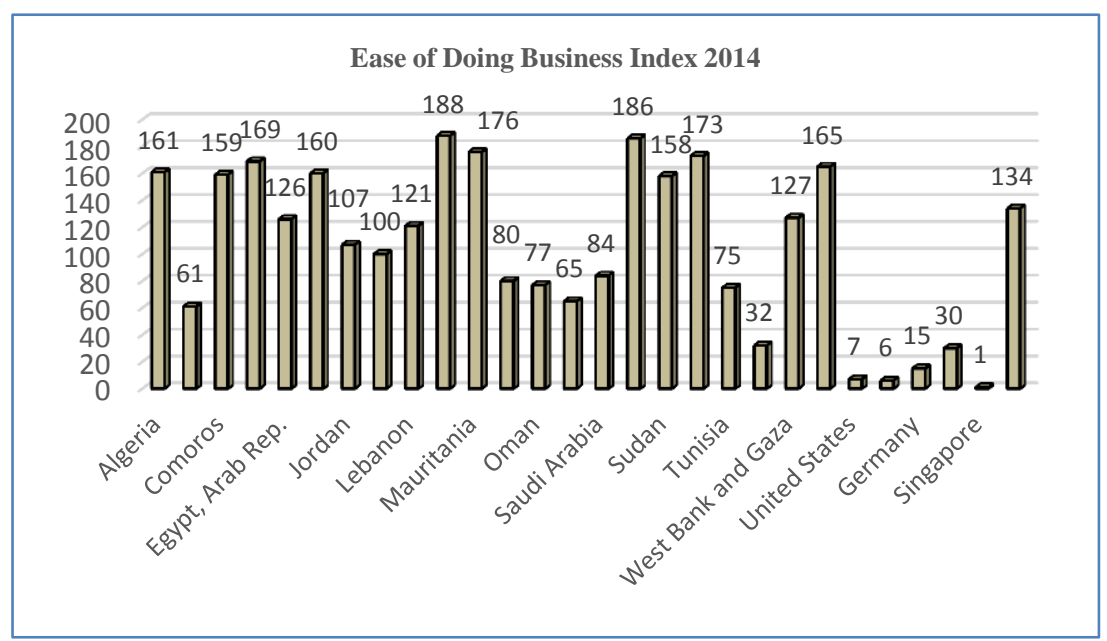

Figure 3. Ease of doing business in the Arab region (World Bank, doing business database 2015)

Another crucial element of the institutional framework is the quality of governance. The Heritage Foundation indices on economic freedom (Note 2) are important indicators to evaluate the level of government effectiveness in the region. Figure 4 indicates that the results are mixed within the region. Some countries such as Algeria, Comoros, Mauritania and Yemen for instance have lower economic freedom indices. Other countries such as UAE, Bahrain and Qatar have indices closely matching those of other developed economies such as the US and Germany. However, when looking at the subcomponents making up the overall economic freedom score, results may differ; for example, it seems that the majority of the Arab region is falling behind when it comes to the degree of "business freedom" and "freedom from corruption" (Appendix I).

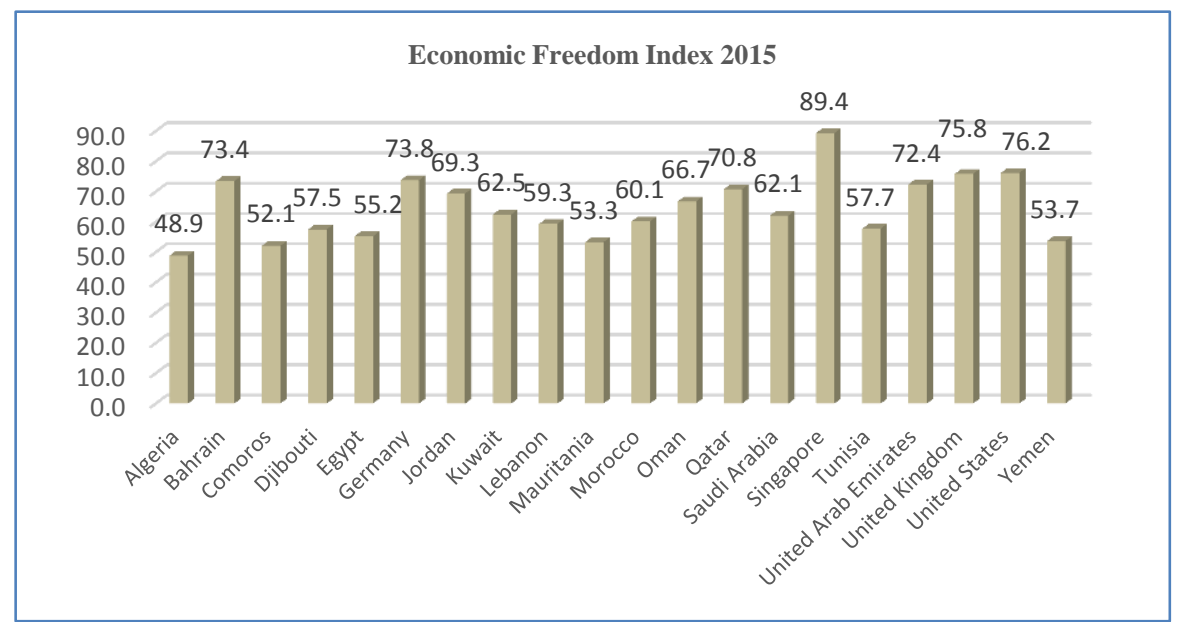

Figure 4. Economic freedom index 2015 (The Heritage foundation, 2015)

This result is consistent with the World Bank ease of doing business data presented above. Therefore, with these statistics in mind, it is evident that although varying in significance within the Arab region, corruption issues along with inflexible investment climates are a major problem. These are major determinants towards incentivizing the inflows of FDIs into the region, and thus deserve to be focused on in this research. Furthermore, our analysis will include both aggregate and firm-level data in order to account for differences within the region pertaining to analyzing FDI spillovers, which is something that has not yet been done in the literature.

Following this overview of the state of FDI inflows and institutional barriers in the Arab region, it is now crucial to link all these elements together and present a comprehensive research illustrating how institutional constraints can hinder not only FDI inflow levels, but also reduce the effectiveness of potential spillovers. Section II presents a selection of the literature clarifying the relationship between growth and FDIs as well as how 
institutional factors affect spillovers. Section III will explain the theoretical background and data methodology approaches using endogenous growth models. Section IV will briefly present a description of the regional and firm-level data used in the analysis. Section V will include the empirical data analysis for both aggregate regional data, and firm-level data. Finally, Sections VI, VII, and VIII will cover concluding remarks, a selection of policy implications and short notes regarding further research in this area.

\section{Literature Review}

This section will present a selection of the literature that will first clarify the relationship between foreign direct investment (FDI) and economic growth. Second, the notion of associated "spillover" effects with recipients of FDIs is highlighted. Third, how the investment climate might act as a factor affecting the growth potentials of FDIs is presented. Fourth, a presentation of literature exploring different models to measure technology spillovers from FDIs will be analyzed. Finally, the review will examine how this relationship between FDIs, spillover effects, and economic growth has been explored within the Arab region.

\subsection{Foreign Direct Investment (FDI) and Economic Growth}

Foreign direct investment has been linked to economic growth, especially in terms of the "positive externalities" that are associated with its presence. The impact of FDIs on economic growth had first taken focus in new endogenous growth models, focusing on the works of Romer, Lucas, and others, following the "neoclassical" theories supported by Solow, and Cobb-Douglas, which didn't fully recognize the effect of FDIs on technology; these models and their techniques will be examined further below. Upon the introduction of these endogenous growth models, many studies have begun to examine the relationship between growth and FDIs. For example, a study examining the impact of FDIs on the economic growth trends in Indian and Chinese economies found a positive impact that contributed to an increase in per capita income (Iqbal et al., 2013). Moreover, the World Bank indicated the importance of FDIs in contributing to the development of Sub-Saharan African countries (Farole \& Winkler, 2014). Al-Shammari and Al-Saran (2012) examine the main determinants of FDI across developing Asia. They find that main factors determining FDI in Asian developing countries are market size, development in the infrastructure, trade openness, financial developing, economic growth and labor. In addition to many other studies that support this relationship in various economies, there has been an emphasis on how FDIs might contribute to economic growth. In other words, having seen how FDIs increased per capita income, it is important to ask, what factor contributed to the positive effect of FDIs on economic growth?

The answer to this question lies in analyzing the impact of FDIs on "technology" which can also be represented as a proxy for human capital (skills, or "knowledge"). This idea takes is linked to the new endogenous growth theories discussed above. Following Solow and Cobb-Douglas models (neoclassical) that focus on capital accumulation as the main contributor to economic growth (Romer, 2012), it is necessary to refer to models that recognize an underlying factor contributing to growth, i.e. exploring the element of technology or knowledge. The endogenous growth theories therefore can be relied on to explain the impact of FDIs on the element of knowledge and hence, on economic growth (Romer, 2012).

\subsection{FDIs and Spillover Effects: Analyzing Technology Spillovers}

After recognizing the important relationship between FDIs and economic growth, the next step is to now build upon the arguments brought about by these new endogenous growth theories, and investigate how FDIs may lead to economic growth through the element of technology. Based on a survey of the literature, studies have indicated a "spillover effect" or a positive externality on host countries from FDI inflows. This spillover effect has been in the form of technology transfer. For example, referring back to the study by the World Bank, results show that FDIs in developing countries serve as valuable sources of knowledge and technology that assist in developing local economic units (Farole \& Winkler, 2014, p. 247). Furthermore, when examining a study on FDI impacts on Mexico and Costa Rica, FDIs have a positive impact "at the macro level through increases in investment, employment, foreign exchange, and tax revenue, and at the micro level through positive spillovers that will advance the host country's knowledge-based assets" (Paus \& Gallagher, 2007, p. 54). A study by Amann and Virmani (2015) ensures the impact of FDI on productivity growth across OECD countries. A theoretical paper by Perri and Peruffo (2016) argues that the model of FDI knowledge spillover should include the macro- level as well as micro -level aspects of spillovers. A study by Wang, Ning, Li. and Prevezer (2016) finds positive influence of FDI on technological spillovers in China. The later result is also consistent with Wang, Liu, Cao, and Wang (2016) where technology spillover is found across varies industrial sectors in China.

Additional studies by De Mello (1999), Obwona (2001) and Borensztein et al. (1998), all emphasize the potential of FDIs on contributing to the transfer of technology to host countries, and even suggest that this contribution may account for growth more than domestic investment would (Hussien, 2009). Again, in making this argument, 
the endogenous growth models were used to examine FDI impacts on knowledge spillovers. Thus, based on these findings, it can be concluded that one of the ways in which FDIs lead to economic growth is through the transfer in technology (which support the ideas in the endogenous growth theories). The next step is to examine the extent in which FDIs can lead to these positive externalities, and what factors would affect the magnitude of these spillovers.

\subsection{Analyzing the Relationship between FDIs and Institutional Capacities}

When analyzing the impact of FDIs on economic growth, it is clear that some shortages might occur in terms of how much FDIs contribute to knowledge spillovers. Thus, under what conditions would FDIs lead to positive technology spillover effects? According to the World Bank's report on FDI spillovers in Sub-Saharan Africa, there exist constraints that categorize into: foreign firm characteristics, domestic firm characteristics, transmission channels (supply chains, labor turnover, market restructuring), host country factors and institutional frameworks (Farole \& Winkler, 2014). Specifically, in chapter three and four of this report, Farole and Winkler (2014) uses an empirical approach to evaluate which absorptive capacities facilitate FDI linkages, by using simple regressions to clarify the impact of this factor on FDI spillovers (pp. 71, 97). Having clarified these important factors, it is apparent that the "absorptive institutional capacity" in the host country is a major factor towards fully realizing FDI positive externalities. This factor has been emphasized in a research by the OECD investigating the potentials of FDIs in China; by using a simple production function (measuring FDI as an exogenous variable impacting the endogenous variable, output), the study concluded that the quality of FDI inflows along with the complementary assets in host regions are main determinants of knowledge-based externalities (Fu, 2008).

Furthermore, another study by Paus and Gallagher (2001) investigates the missing link found in FDIs in Costa Rica and Mexico; the results indicate that the missing links involve poor government strategy to direct the potentials of FDIs into their governing and economic system, as well as the failure of local institutions to provide supportive inputs that meet the standards of inflowing transnational corporations (TNCs). This again emphasized the role of institutional variables in contributing to the host country's "absorptive capacity" which will in turn lead to positive FDI spillovers (2001, p. 58). Moreover, another study investigates investment climates by using the World Bank's "ease of doing business" indicators, and focusing on a selection of developing countries (Bayraktar, 2013). The methodology used was a simple correlation matrix, which would examine the effects of "ease of doing business" indicators on FDI levels; results indicated that countries with less constraints towards doing business tend to attract more FDI inflows (2013).

This concept has also been emphasized in a study examining FDIs in China and India; results indicated that economic activity, infrastructure, political system, and the business environment of the host country were major factors affecting FDI levels (Iqbal et al., 2013). Therefore, when looking at all of these studies, it is clear that there is an important correlation between institutional capacities and the potential of positive FDI spillovers, or externalities. This in turn makes it worthwhile to consider this factor when analyzing FDI spillovers for the case of the Arab Region.

\subsection{FDIs, Spillovers Effects and Economic Growth: The Case of the Economies of the Arab Region}

The literature also covers research in this topic pertaining to the cases in the Arab region. A study examining the effects of FDIs on GCC economies using a heterogeneous panel analysis, results in findings that align with the propositions of the endogenous growth theories (Al-Iriani, 2007). Furthermore, supporting the arguments about institutional capacities, this paper also states that GCC countries can further benefit from FDIs improving their transparency, policies, legal systems, and institutions (Al-Iriani, 2007). Furthermore, a study examining the effects of FDIs on 16 Arab countries using a dynamic panel analysis, concludes that the current impact of FDIs is limited or negligible; however, it also mentions that findings indicate factors that are hindering the positive potential benefits that FDIs offer these countries such as financial development, trade openness, human capital and infrastructure quality (El- Wassal, 2012).

Another study by Al-shammari, Al-halaq, and shammari (2016) investigates determinants of FDI inflow for Kuwait. they find that macroeconomic factors such as of market size, economic development, financial deepening, infrastructure development, openness are in the long and short runs related to FDI inflows in Kuwait. Other studies in the MENA region also indicate that institutional variables such as property rights for example, are one of the key determinants of FDI inflows in the region (Mohamed \& Sidiropoulos, 2010). Moreover, according to an Economic Update Report published by the National Bank of Kuwait (2014), the GCC region has been aiming to improve their business environments especially in terms of enhancing the ease of doing business factors (starting business, obtaining credit, enforcing contracts etc.) in order to encourage FDI inflows into the 
region. This further supports the relevance of this research in terms of focusing on institutional factors such as investment climates in examining the full potential of FDIs on the Arab economies.

Thus, this literature review has presented a background supporting a positive relationship between FDI and economic growth, through its ability to provide technology spillover effects. Furthermore, institutional capacities act as major factors impacting the full potentials of FDI knowledge spillover effects. These relationships were then supported by taking a look at new endogenous growth theory models and some international trade theory models. Finally, the implications of these relationships and concepts in the context of the Arab region were examined. Now that these factors, relationships, and concepts have been identified, it is time to apply a selected methodology to investigate FDIs and knowledge spillovers taking into consideration institutional capacities as a major barrier, for the case of the Arab region.

\section{Methodology}

The main approach in analyzing the impact of institutional factors on FDI spillovers is to divide the analysis into two levels; an aggregate, macroeconomic regional-level analysis, and a microeconomic firm-level analysis. This will provide a holistic analysis of the performance of FDIs in the region given the environmental (institutional) factors that may differ from one country to another. Models will be based on the concepts explored in new endogenous growth theories to compute the spillover effects at the firm-level and regional-level starting off with the general production function as a base,

$$
Y=A L^{\beta} K^{\alpha}
$$

in which Y (output) is a function of A (technology), L (labor), and K (capital) (Note 3). Building on this basic production function, the general form of the endogenous growth model can be derived,

$$
\dot{A}(t)=B\left[a_{k} K(t)\right]^{\beta}\left[a_{L} L(t)\right]^{\gamma} A(t)^{\theta} \text { such that } B>0 \beta \geq 0 \gamma \geq 0
$$

in which the growth of technology or knowledge $\dot{A}(t)$ is a function of the stock of capital, labor, and technology (Romer, 2012). Thus, it is "endogenous" since the stock of knowledge $A(t)^{\theta}$ is a variable affecting the growth of knowledge $\dot{A}(t)$. In using this concept, it is possible to analyze the impact of the stock of FDI inflows (representing the stock of knowledge $A(t)^{\theta}$ ) on FDI spillovers (representing the growth of knowledge $\dot{A}(t)$ ) while considering control variables as well as variables representing institutional factors. For the regional analysis, adapting the same concept of the general endogenous growth model, the industry value added as a percentage of GDP IndVA serves as a proxy for FDI spillovers. Control variables affecting spillovers include gross capital formation as a percentage of GDP GCF, labor productivity $L P$ (or GDP per person employed as reported by the World Bank), trade openness Trade (or trade as a percentage of GDP), and economic growth GR (or annual percentage growth rate of GDP at market prices based on constant local currency). The stock of FDI inflows FDI (net inflows in current US dollars) as well as proxies for institutional factors that might affect FDI spillovers Inst $F$ will also be included within the model. The regional-level model is expressed below,

$$
I n d V A=\alpha+F D I+G R+L P+G C F+\text { Trade }+ \text { Inst } F+\varepsilon
$$

For the cross-country firm level analysis, the endogenous model will take the following form (Note 4),

$$
N S_{i j}=\alpha+F D I_{i j}+L P_{i j}+F C_{i j}+I n s t F_{i j}+\varepsilon
$$

The dependent variable $N S_{i j}$ represents net annual sales (total sales minus the total cost incurred, which reflects the "value added" for the firm) for time period $i$ and industry $j$. For the case of the independent variables, $F D I_{i j}$ represents the ownership share of private foreign individuals, companies or organizations, $L P_{i j}$ refers to labor productivity (effective labor) which is quantified by using values for the education level of the firm's employees and managers. Moreover, $F C_{i j}$ represents capital formation within the firm quantified as the net value of assets after depreciation for land and buildings, and $I n s t F_{i j}$ represents institutional factors facing the firms.

\section{Data Description}

For the regional model, the selected variables are all extracted from the World Bank's World Development Indicators 2015 database, with proxies for institutional barriers extracted from the World Bank's Worldwide Governance Indicators database. This regional panel dataset is comprised of 12 Arab countries (Note 5), with time series ranging from 1996 till 2014; data gaps do exist according to the availability of data for each country (Note 6). For this microeconomic analysis, data is obtained from the World Bank Enterprise Surveys for five Arab countries (Note 7) for years 2013 or 2014, depending on the latest survey datasets available for each country. Variables used as proxies reflecting institutional factors are based on survey responses by firms on how severe a certain obstacle is in hindering their performance. These five countries are also included in the regional, aggregate analysis, and will therefore provide clearer idea of differing trends within the region in terms of the 
potential of FDI spillovers.

\section{Empirical Results and Analysis}

Having set the aggregate regional and firm-level endogenous models, it is now important to direct the analysis towards a linear ordinary least squares (OLS) regression analysis, which will identify the impact of selected institutional factors on the potential magnitude of FDI spillovers.

\subsection{FDI Spillovers in the Arab Region: An Aggregate Regional Analysis}

Starting off with the regional endogenous growth model, the results below indicate findings corresponding to what the literature has reported. FDI inflows are significantly positively correlated with the industry value added variable. This supports the notion of the endogenous growth theory in which the stock of technology is an important factor affecting the growth of technology (or spillovers). Having this finding be consistent with the theoretical base, it is possible to look at how other factors affect FDI spillovers. The most surprising result is having one of the control variables, trade openness, be significantly negative to the industry value added. This result could be explained by the fact that the majority of the data sample countries are importers; a deficiency in an economy's trade balance usually negatively affects growth or output, which is the case in this model. Labor productivity measured as GDP per person employed serves as a factor significantly and positively affecting spillovers which is consistent with the theoretical model.

Table 1. Aggregate regional analysis of FDI spillovers

\begin{tabular}{ccccccc}
\hline IndVA & Coef. & Std. Err. & $\mathbf{t}$ & $\mathbf{P > t}$ & [95\% Conf. & Interval] \\
\hline FDI & $2.90 \mathrm{E}-10$ & $1.13 \mathrm{E}-10$ & 2.57 & 0.012 & $6.58 \mathrm{E}-11$ & $5.14 \mathrm{E}-10$ \\
GR & 0.2081814 & 0.2555394 & 0.81 & 0.417 & -0.2994161 & 0.715779 \\
GCF & 0.0281398 & 0.1518185 & 0.19 & 0.853 & -0.2734289 & 0.3297085 \\
Trade & -0.2765657 & 0.0391606 & -7.06 & 0.000 & -0.3543534 & -0.198778 \\
LP & 0.00151 & 0.0001397 & 10.81 & 0.000 & 0.0012325 & 0.0017875 \\
Regulatory Quality & 0.3911266 & 0.0645759 & 6.06 & 0.000 & 0.2628545 & 0.5193986 \\
Constant & 13.12441 & 3.937303 & 3.33 & 0.001 & 5.303443 & 20.94538 \\
\hline
\end{tabular}

Looking at the variable of interest, the value of "regulatory quality perception" is selected as a proxy for institutional factors (extracted from the Worldwide Governance Indicators database). In this case it is clear that as regulatory quality is enhanced, FDI spillovers will increase (because of the positive and significant relationship between the variables). Similar results were obtained when looking at other governance variables such as "government effectiveness," "control of corruption," "law perception" and "voice accountability" (results in Appendix III). Therefore, based on these aggregate empirical results, institutional quality is a major factor in determining the effective magnitude of FDI spillovers on the economies of the Arab region. Hence, these results are consistent with the major propositions of the endogenous growth model. This empirical model reported to have a $76.9 \%$ adjusted $\mathrm{R}$-squared value, indicating a strong model with exogenous variables effectively explaining their effects on the endogenous variable.

\subsection{FDI Spillovers in Arab Businesses: A Firm-Level Analysis}

The firm-level analysis will focus on the impact of legislative or institutional constraints on the performance of a sample of firms, in terms of accounting for the percentage of firms with international ownership. For the case of this analysis, it is important to see the extent in which FDIs are an important part of the performance of the firm or not, for each Arab country. Starting off with Jordan (2013), the results below (Note 8) indicate that the presence of foreign ownership in local firms have a significantly positive effect on business' net sales, which supports the endogenous growth theory whereby FDI spillovers lead to greater productivity and growth (here demonstrated at a firm-level by increased sales). Moreover, there are positive significant relationships between other control variables such as capital stocks, and direct exports (a proxy for trade openness from our general endogenous model). When looking at the variables of interest, the only significant institutional factor that affects net sales in businesses in Jordan is corruption; this infers that local enterprises face corruption as a major obstacle towards their growth (based on their survey response), and that higher corruption weight thus transcends into lower sales (explaining the negative coefficient). Hence, results in Jordan support this paper's hypothesis and are consistent with the aggregate regression model. 
Table 2. Jordan (2013) firm-level analysis

\begin{tabular}{ccccccc}
\hline Net Sales & Coef. & Std. Err. & $\mathbf{t}$ & $\mathbf{P > t}$ & {$[\mathbf{9 5 \%}$ Conf. } & Interval] \\
\hline Foreign Ownership Share & 66719.09 & 19803.79 & 3.37 & 0.001 & 27777.32 & 105660.8 \\
Capital: Land and Buildings & 1.54161 & 0.182214 & 8.46 & 0.000 & 1.183309 & 1.899911 \\
Direct Exports & 55221.18 & 16287.3 & 3.39 & 0.001 & 23194.19 & 87248.18 \\
Business Licensing Obstacles & -19466.91 & 374439.2 & -0.05 & 0.959 & -755756.1 & 716822.3 \\
Political Instability Obstacle & 285041.7 & 322069.5 & 0.89 & 0.377 & -348269 & 918352.4 \\
Corruption Obstacle & -409094.6 & 188012 & -2.18 & 0.03 & -778797.3 & -39391.8 \\
Regulatory Policy Uncertainty Obstacle & 466874.9 & 244111.9 & 1.91 & 0.057 & -13141.57 & 946891.3 \\
Labor Regulations Obstacle & -620964.3 & 471061.7 & -1.32 & 0.188 & -1547250 & 305321.6 \\
Constant & 356072.9 & 767480.4 & 0.46 & 0.643 & -1153084 & 1865230 \\
\hline
\end{tabular}

Moving on to the case of Egypt (2013), the results are more ambiguous, especially in terms of the significance of the presence of foreign shares (FDIs) to the total sales (Note 9) outcomes of local firms. This can be explained by the politically unstable environment in Egypt, especially after the Arab Spring movement. Thus, FDI inflows may not be an important factor in determining the direction of sales in local firms because of its lack of presence. The estimated correlation index between sales and foreign ownership shares is 0.043 , which indicates a positive but insignificant relationship. Similar findings were obtained when analyzing Tunisia (2013), with a correlation index of 0.013 between sales and foreign ownership.

For the case of Lebanon (2013), the regression results (Note 10) show significant relationships between our control variables (foreign ownership, capital stock, and direct exports) and total annual sales, however, the significance of the institutional variables of interest are absent. Although variables such as informal competition, business licensing, corruption and labor regulations are negatively related to the performance of businesses (i.e. negatively affecting the potentials of FDI spillovers), there are not significant. Thus, in this case, factors other than institutional constraints explain hindrances towards FDI spillover performance.

Table 3. Lebanon (2013) firm-level analysis

\begin{tabular}{|c|c|c|c|c|c|c|}
\hline Total Annual Sales & Coef. & Std. Err. & $\mathbf{t}$ & $\mathbf{P}>\mathbf{t}$ & [95\% Conf. & Interval] \\
\hline Foreign Ownership Share & $3.03 \mathrm{E}+08$ & $1.31 \mathrm{E}+08$ & 2.33 & 0.021 & $4.62 \mathrm{E}+07$ & $5.61 \mathrm{E}+08$ \\
\hline Capital: Land and Buildings & 1.995297 & 0.267278 & 7.47 & 0.000 & 1.468489 & 2.522105 \\
\hline Direct Exports & $1.12 \mathrm{E}+08$ & $5.45 \mathrm{E}+07$ & 2.06 & 0.040 & 4953821 & $2.20 \mathrm{E}+08$ \\
\hline Employees' Education Level & $7.93 \mathrm{E}+07$ & $1.98 \mathrm{E}+08$ & 0.4 & 0.689 & $-3.11 \mathrm{E}+08$ & $4.70 \mathrm{E}+08$ \\
\hline Customs/Trade Regulations Obstacle & $4.14 \mathrm{E}+08$ & $6.94 \mathrm{E}+08$ & 0.6 & 0.551 & $-9.53 \mathrm{E}+08$ & $1.78 \mathrm{E}+09$ \\
\hline Informal Competition Obstacle & $-3.05 \mathrm{E}+08$ & $5.03 \mathrm{E}+08$ & -0.61 & 0.545 & $-1.30 \mathrm{E}+09$ & $6.86 \mathrm{E}+08$ \\
\hline Business Licensing Obstacles & $-3.90 \mathrm{E}+08$ & $8.36 \mathrm{E}+08$ & -0.47 & 0.641 & $-2.04 \mathrm{E}+09$ & $1.26 \mathrm{E}+09$ \\
\hline Political Instability Obstacle & $2.51 \mathrm{E}+08$ & $1.86 \mathrm{E}+09$ & 0.13 & 0.893 & $-3.42 \mathrm{E}+09$ & $3.92 \mathrm{E}+09$ \\
\hline Corruption Obstacle & $-3.08 \mathrm{E}+08$ & $1.05 \mathrm{E}+09$ & -0.29 & 0.769 & $-2.37 \mathrm{E}+09$ & $1.76 \mathrm{E}+09$ \\
\hline Labor Regulations Obstacle & $-1.64 \mathrm{E}+09$ & $1.49 \mathrm{E}+09$ & -1.1 & 0.273 & $-4.57 \mathrm{E}+09$ & $1.30 \mathrm{E}+09$ \\
\hline Regulatory Policy Uncertainty Obstacle & $3.43 \mathrm{E}+08$ & $5.20 \mathrm{E}+08$ & 0.66 & 0.511 & $-6.83 \mathrm{E}+08$ & $1.37 \mathrm{E}+09$ \\
\hline Constant & $3.76 \mathrm{E}+09$ & $6.32 \mathrm{E}+09$ & 0.6 & 0.552 & $-8.70 \mathrm{E}+09$ & $1.62 \mathrm{E}+10$ \\
\hline
\end{tabular}

Mauritania (2014) exhibited results (Note 11) similar to Lebanon, with significant contributions of FDIs to total annual sales (spillovers), however, the only significant variable of interest is access to finance as an obstacle. Thus, institutional framework may not be as important in affecting FDI performance, in comparison to financial resources. However, institutional and financial constraints are interrelated; therefore, even though institutional variables of interest below don't exhibit significant relationships, this doesn't completely negate their importance. Having a stable institutional environment can help relieve financial obstacles within the economy.

Table 4. Mauritania (2014) firm-level analysis

\begin{tabular}{ccccccc}
\hline Total Annual Sales & Coef. & Std. Err. & $\mathbf{t}$ & $\mathbf{P}>\mathbf{t}$ & {$[\mathbf{9 5 \%}$ Conf. } & Interval] \\
\hline Foreign Ownership Share & $2.95 \mathrm{E}+07$ & $1.10 \mathrm{E}+07$ & 2.67 & 0.011 & 7217315 & $5.18 \mathrm{E}+07$ \\
Capital: Land and Buildings & 4.061968 & 3.943557 & 1.03 & 0.309 & -3.902208 & 12.02614 \\
Employees' Education Level & $-3.40 \mathrm{E}+07$ & $2.53 \mathrm{E}+07$ & -1.34 & 0.187 & $-8.50 \mathrm{E}+07$ & $1.71 \mathrm{E}+07$ \\
Business Licensing Obstacles & $1.16 \mathrm{E}+08$ & $2.08 \mathrm{E}+08$ & 0.56 & 0.580 & $-3.05 \mathrm{E}+08$ & $5.37 \mathrm{E}+08$ \\
Political Instability & $1.58 \mathrm{E}+08$ & $2.46 \mathrm{E}+08$ & 0.64 & 0.525 & $-3.39 \mathrm{E}+08$ & $6.55 \mathrm{E}+08$ \\
Corruption Obstacle & $-2.01 \mathrm{E}+08$ & $1.96 \mathrm{E}+08$ & -1.03 & 0.310 & $-5.97 \mathrm{E}+08$ & $1.94 \mathrm{E}+08$ \\
Access to Land Obstacle & $2.26 \mathrm{E}+08$ & $2.02 \mathrm{E}+08$ & 1.12 & 0.270 & $-1.82 \mathrm{E}+08$ & $6.34 \mathrm{E}+08$ \\
Access to Finance Obstacle & $-9.23 \mathrm{E}+08$ & $3.22 \mathrm{E}+08$ & -2.86 & 0.007 & $-1.57 \mathrm{E}+09$ & $-2.72 \mathrm{E}+08$ \\
Constant & $2.27 \mathrm{E}+09$ & $7.69 \mathrm{E}+08$ & 2.96 & 0.005 & $7.22 \mathrm{E}+08$ & $3.83 \mathrm{E}+09$ \\
\hline
\end{tabular}




\section{Conclusions}

According to endogenous growth theory models and empirical case studies, FDIs are important contributors to economic growth especially in terms of their potential knowledge spillover effects. Much of the literature has pinpointed institutional constraints as major obstacles affecting the positive externalities of FDIs on growth, especially in terms of the host economy's "absorptive capacity" or its ability to handle advanced, incoming investment from abroad. When analyzing the case of the Arab region, there is a recent decline in the inflows of FDIs, and this research aims to analyze why this decline might have occurred, by focusing on the investment climate as a determining factor of incentivizing foreign investment. The analysis showed that both at a regional and firm-level perspective, institutional constraints are in fact major factors to consider when analyzing their impact in attracting FDIs; variances in significance differ from one country to another usually depending on the political nature of the country or its economic framework.

Based on the firm-level analysis, for some Arab countries within the region, FDIs play an important role in increasing firm-level performances, as shown by increased total or net sales; these highlight the potential of knowledge spillover effects that the endogenous growth model supports. However, these spillovers are less significant in some countries especially those with recent political instabilities arising from the Arab Spring aftermath, due to the fact that the actual FDI stocks may be significantly lower than other countries. Furthermore, some countries account for factors other than institutional barriers to affect the performance of their FDI spillovers, but as mentioned above, it is important to note that different categories of barriers are closely related and are often interdependent, thus not completely considering institutional constraints as negligible.

\section{Policy Recommendations}

Based on the obtained results, the institutional framework is an important barrier towards the potential of positive FDI spillovers on the economies of the Arab region (especially in terms of the quality of governance), even though it may be less significant in certain Arab countries. Thus, it is crucial to examine potential policy proposals aiming to relieve these institutional barriers to FDI spillovers. This paper's findings are generally consistent with the literature, hence emphasizing the need to focus on the "absorptive capacity" of these economies, as clarified in the World Bank report on FDIs in the sub-Saharan African region (Farole \& Winkler, 2014).

A crucial approach to improving the absorptive capacities is to have targeted FDI policy actions, whereby incentives are enhanced for inward FDI flows, while simultaneously attracting their spillovers towards the region's economic growth. The importance of having such targeted policies is accentuated in economic theory as well as within the literature covering this topic; FDIs are an important contributor to holistic economic growth and development, and targeted policies aiming to improve their performance, can be especially beneficial for economies in the region that need a diversified source of growth (such as oil-exporting GCC countries).

As demonstrated by the endogenous growth model, the technology spillovers arising from FDI inflows has an implicit impact of growth through the transfer of "knowledge." This can in turn enhance human capital levels, innovation, and other forms of development. Having this can of diversified source of growth (even though it is indirect or implicit), can be extremely beneficial for non-diversified economies of the GCC region for instance. In determining how to set the preferred set of targeted policies, we must first examine the different components that make up an economy's "absorptive capacity;" these components are comprised of many different factors that are interdependently related (Farole \& Winkler, 2014). Specifically, the absorptive capacity links the institutional framework as well as firm-level characteristics into ultimately affecting the outcome of FDI spillovers. Policies to tackle the subcomponents under these two broad categories include emphasizing the government's role in institutional development.

For example, the government should work to develop "an environment that supports the growth and dissemination of innovative technologies for and by SMEs to take advantage of the knowledge-based economy" (Emine, 2012, p. 28). Moreover, government policy plans should "maintaining close integration" between the policies pertaining to private sector businesses and to that of general economic policy; this consistency within general economic policies would create a more stable environment for these businesses to further develop within the scope of the general economy (Alasarg, 2006, p.11); more developed businesses will in turn enhance the absorptive capacity, thus attracting more FDIs. Attracted FDIs would eventually lead to even further growth through the transmission of positive externalities. Other targeted policies should also ease institutional constraints and enhance investment climates; for example, in the region, the "ease of doing business" as shown above, ranks well below the average levels, thus dampening the potentials of FDI inflows and spillovers. Targeted policies aiming to enhance regulations for startups are an essential component of an economy's 
absorptive capacity, in order to attract FDIs.

Other major factors pertaining to the Region's absorptive capacity relates to the problem of information asymmetry. Research has noted that transparency issues are important impediments towards businesses in the Arab world; thus, policies aiming to maintain stability and transparency within institutions in the economy must be considered. Certain studies also recommended the creation of a line of communication between various organizations and bodies responsible for the development of local enterprises (Alasarg, 2006, p.13). This communication should be inter-sectoral between businesses, government institutions (like public funds, ministries, etc.), and even financial intermediaries. Having a clear correspondence between these different sectors can help reduce information gaps, thus creating a more attractive investment climate for FDIs. Furthermore, this is also related to corruption; policies directed towards eliminating or reducing corruption levels are important for the effectiveness of FDI spillovers in the Region, as revealed in the empirical results. Policies that reduce information asymmetry will in turn reduce corruption levels, since illicit actions will be transparent, thus incentivizing each sectors to act within the rule of law.

Another important policy area to consider is in terms of enhancing human capital levels in the region. Human capital serves to be an important component of the absorptive capacity framework (Farole \& Winkler, 2014). According to the data from the World Bank's World Enterprise Surveys, underdeveloped skills, education, and experience (which are tenets of human capital development) seem to be the most important managerial obstacles cited in the Arab world; undereducated workers can not only contribute to lower revenues, but can also contribute to lower employment contributions as a consequence of lower sales. Foreign investment would not flow inwards towards economies with a shortage of human capital, since these economies would not be able to "absorb" the advanced level of these investments. Policies to enhance human capital skills is a vast area which includes many subcategories; for instance, policies may be as broad as improving the education system in the region, the school-to-work transition, and as narrow as improving at-work training programs for employees.

Since this research pertains to handling the institutional framework aiming to improve the absorptive capacity, policies can include improving regulations in the labor market that ease school-to-work transitions for fresh graduates. The labor market structure is facing severe problems in terms of having correct "signaling" between the supply (graduates from universities) and demand (businesses in the labor market) elements in the region (Faour, 2015); thus, enhancing institutional factors such as solving problems of meritocracy deficits in the labor market, is necessary to ensure the optimal human capital development, therefore enabling foreign investments to benefit from local talent and skills. Another policy direction would be improve financial resources for businesses by having cooperation between public and private educational and research institutions as that would increase the educational and technological capabilities of SMEs (Emine, 2012, p. 28). This cooperation between the two sectors would be essential to overcoming managerial barriers faced by local businesses; certain cooperative decisions may include working on creating efficient training programs in areas that employees need the most for instance. All in all, these policy implications will enhance the business climate to allow the local businesses to thrive in the region, while simultaneously multiplying the potential for growth by attracting FDIs with their growth-promoting spillovers.

\section{Further Research}

Although this research has provided sufficient evidence on the importance of improving the institutional framework in the Arab region, there are many shortages that may be taken into consideration in attempting future work in this research area. Further studies would include a larger sample size, a wider selection of variables of interest (especially proxies for determining factors of FDI spillover performance such as R\&D investments in the Arab region), and may even include analyzing other dimensions aside from institutional quality, such as foreign firm characteristics, or the labor market supply and demand channels. Furthermore, additional analyses on comparing intra-industry data results within selected Arab economies may provide interesting insights as to which industry or sector would most benefit from FDI spillovers.

\section{References}

Alasarg, H. (2006). Enhancing Competitiveness for SMEs in the Arab Countries. Ministry of Trade and Industry. $1-20$.

Al-Irani, M. (2007). Foreign Direct Investment and Economic Growth in the GCC Countries: A Causality Investigation Using Heterogeneous Panel Analysis. Topics in Middle Eastern and North African Economies. 9.

Al-Shammari, N. N., \& Al-Sarhan, A. A. (2012). Foreign Direct Investment in Developing Asia according to the 
Location Advantage Hypothesis. Arab Journal of Administrative Sciences, 19(3).

Al-Shammari, N., Al-Halaq, S., \& Al-Shammari, D. (2016). Testing The FDI Hypothesis Of Location Advantage In The Case Of Kuwait. Journal of Applied Business Research, 32(2), 597. https://doi.org/10.19030/jabr.v32i2.9598

Amann, E., \& Virmani, S. (2015). Foreign direct investment and reverse technology spillovers. OECD Journal: Economic Studies, 2014(1), 129-153. https://doi.org/10.1787/eco_studies-2014-5jxx56vcxn0n

Bayraktar, N. (2013). Foreign Direct investment and Investment Climate. Procedia Economics and Finance, 83-92. https://doi.org/10.1016/S2212-5671(13)00013-0

Borensztein, E., De Gregorio, J., \& Lee, J. W. (1998). How does foreign direct investment affect economic $\begin{array}{llll}\text { growth? Journal of International } & \text { Economics, } & \text { 45(1), }\end{array}$ https://doi.org/10.1016/S0022-1996(97)00033-0

DeMello, L. R., Jr. (1999). Foreign direct investment-led growth: Evidence from time series and panel data. Oxford Economic Papers, 51(1), 133-151. https://doi.org/10.1093/oep/51.1.133

El-Nakib, O. (2014, August 5). Economic Update: GCC: FDI down for fifth year in a row; Kuwait the top Arab investor. NBK Economic Research.

El-Wassal, K. (2012, December). Foreign Direct Investment and Economic Growth in Arab Countries (1970-2008): An Inquiry into Determinants of Growth Benefits. Journal of Economic Development, 37(4), 79-100.

Emine, D. (2012). Financial challenges that impede increasing the productivity of smes in arab region. Journal of Contemporary Management, 17-32.

Faour, M. (2015). Enhancing Employability: The Double Transition from Education to Work in the Arab World Proceedings of the Third Arab Development Symposium. The International Bank for Reconstruction and Development, World Bank and the Arab Fund for Economic and Social Development, 1-31.

Farole, T., \& Winkler, D. (2014). Making Foreign Direct Investment Work for Sub-Saharan Africa: Local Spillovers and Competitiveness in Global Value Chains. World Bank - Directions in Development, 1-279.

Fu, X. (2008, March 27-28). Foreign Direct Investment, Absorptive Capacity and Regional Innovation Capabilities: Evidence from China. OECD Global Forum on International Investment.

Garcia-Bolivar, O. (2006). Informal Economy: Is It A Problem, A Solution, or Both? The Perspectives of the Informal Business (pp. 1-26). Northwestern University School of Law - Law and Economics Papers.

Hale, G., \& Long, C. (2007, February). Are there Productivity Spillovers from Foreign Direct Investment in China? (pp. 1-33). Federal Reserve Bank of San Francisco.

Hussein, M. (2009, April). Impacts of Foreign Direct Investment on Economic Growth in the Gulf Cooperation Council (GCC) Countries. International Review of Business Research Papers, 5(3), 362-376.

Iqbal, Z., Masood, I., \& Ramzan, M. (2013). Foreign Direct Investment and Economic Growth: Comparative Positon of Chinese and Indian Economies. Journal of Business Studies Quarterly, 4(3), 52-61.

Kinda, T. (2010). Investment Climate and FDI in Developing Countries: Firm-Level Evidence. World Development, 38(4), 498-513. https://doi.org/10.1016/j.worlddev.2009.12.001

Leamer, E. (1995). The Heckscher Ohlin Model in Theory and Practice. Princeton Studies in International Finance, 77, 1-50.

Mohamed, S. E., \& Sidiropouls, M. G. (2010). Another Look at the Determinants of Foreign Direct Investment in MENA Countries: An Empirical Investigation. Journal of Economic Development, 35(2), 75-95.

Obwona, M. (2001). Determinants of FDI and their impact on economic growth in Uganda. African Development Review, 13, 46-81. https://doi.org/10.1111/1467-8268.00030

Paus, E., \& Gallagher, K. (2007). Missing Links: Foreign Direct Investment and Industrial Development in Costa Rica and Mexico. St Comp Int Dev., 43, 53-80. https://doi.org/10.1007/s12116-007-9016-2

Perri, A., \& Peruffo, E. (2016). Knowledge Spillovers from FDI: A Critical Review from the International Business Perspective. International Journal of Management Reviews, 18, 3-27. https://doi.org/10.1111/ijmr.12054

Romer, D. (2012). Advanced macroeconomics (4th ed.). New York: McGraw-Hill Companies. 
Wang, H., Liu, H., Cao, Z., \& Wang, B. (2016). FDI technology spillover and threshold effect of the technology gap: regional differences in the Chinese industrial sector. SpringerPlus, 5(1), 1. https://doi.org/10.1186/s40064-016-1962-6

Wang, Y., Ning, L., Li, J., \& Prevezer, M. (2016). Foreign direct investment spillovers and the geography of innovation in Chinese regions: the role of regional industrial specialization and diversity. Regional Studies, 50(5), 805-822. https://doi.org/10.1080/00343404.2014.933800

\section{Notes}

Note 1. Data for the "ease of doing business" index is extracted from the World Bank's Doing Business Database. The index is based on rankings ranging from 1-189, with 1=easiest, 189=most difficult.

Note 2. The Economic Freedom overall index and ranking has many subcomponents that make up the final score. Detailed data on each of these subcomponents are in Appendix I.

Note 3. Growth models may be "labor-augmenting" with technology directly affecting labor, "capital-augmenting" with technology directly affecting capital, or "Hicks-neutral" with technological progress not affecting the balance of labor and capital in the production function (Romer, 2012, p. 10). For this research, we will be looking at general effects of technological progress not limited to affecting a specific input (i.e. Hicks-neutral).

Note 4. This firm-level empirical model is influenced by the methodology used by Hale and Long (2007).

Note 5. Arab countries included in the aggregate panel dataset are: Comoros, Djibouti, Egypt, Jordan, Lebanon, Mauritania, Morocco, Oman, Palestine, Saudi Arabia, Sudan and Tunisia (a total of 12 countries with the time series 1996-2014).

Note 6. Given the limited availability of data for the Arab region, we have selected 12 countries with data from 1996 till 2014, in order to present the most complete dataset, considering the variables of choice.

Note 7. Arab countries included in the firm-level analysis are: Egypt, Jordan, Lebanon, Mauritania and Tunisia.

Note 8. Estimated model adjusted $\mathrm{R}$-squared value $=23.9 \%$

Note 9. Total annual sales are used in some cases instead of net sales based on the availability of sufficient data.

Note 10. Estimated model adjusted $\mathrm{R}$-squared value $=21.7 \%$

Note 11. Estimated model adjusted R-squared value $=20.6 \%$

\section{Appendix A}

\section{Detailed Data on Institutional Constraints}

Table A1. Components of the economic freedom index (Heritage Foundation, 2015)

\begin{tabular}{|c|c|c|c|c|c|c|c|c|c|c|c|c|}
\hline \multirow[b]{2}{*}{ Country Name } & \multirow{2}{*}{$\begin{array}{l}\text { World } \\
\text { Rank }\end{array}$} & \multirow{2}{*}{$\begin{array}{l}2015 \\
\text { Score }\end{array}$} & \multirow{2}{*}{$\begin{array}{c}\text { Property } \\
\text { Rights }\end{array}$} & \multicolumn{9}{|c|}{ Freedom Indices } \\
\hline & & & & Corruption & Fiscal & $\begin{array}{c}\text { Government } \\
\text { Spending }\end{array}$ & Business & Labor & Monetary & Trade & Investment & Financial \\
\hline Algeria & 157 & 48.9 & 30.0 & 36.0 & 80.0 & 38.7 & 66.6 & 50.5 & 71.2 & 60.8 & 25.0 & 30.0 \\
\hline Bahrain & 18 & 73.4 & 60.0 & 48.0 & 99.9 & 73.1 & 72.5 & 83.1 & 74.2 & 78.6 & 65.0 & 80.0 \\
\hline Comoros & 142 & 52.1 & 30.0 & 28.0 & 64.5 & 78.8 & 47.3 & 52.0 & 77.9 & 73.0 & 40.0 & 30.0 \\
\hline Djibouti & 112 & 57.5 & 25.0 & 36.0 & 81.2 & 57.1 & 55.4 & 66.6 & 78.9 & 54.8 & 70.0 & 50.0 \\
\hline Egypt & 124 & 55.2 & 20.0 & 32.0 & 85.8 & 68.0 & 65.4 & 53.6 & 67.4 & 70.0 & 50.0 & 40.0 \\
\hline Germany & 16 & 73.8 & 90.0 & 78.0 & 60.8 & 40.1 & 88.2 & 51.2 & 81.5 & 88.0 & 90.0 & 70.0 \\
\hline Jordan & 38 & 69.3 & 60.0 & 45.0 & 93.7 & 70.7 & 59.1 & 74.4 & 80.6 & 79.6 & 70.0 & 60.0 \\
\hline Kuwait & 74 & 62.5 & 45.0 & 43.0 & 97.7 & 61.1 & 58.6 & 64.2 & 74.0 & 76.2 & 55.0 & 50.0 \\
\hline Lebanon & 94 & 59.3 & 20.0 & 28.0 & 91.3 & 70.6 & 54.7 & 60.7 & 72.0 & 75.8 & 60.0 & 60.0 \\
\hline Mauritania & 135 & 53.3 & 25.0 & 30.0 & 80.2 & 59.8 & 50.5 & 52.1 & 76.6 & 69.0 & 50.0 & 40.0 \\
\hline Morocco & 89 & 60.1 & 40.0 & 37.0 & 70.9 & 61.0 & 68.8 & 33.4 & 81.9 & 78.2 & 70.0 & 60.0 \\
\hline Oman & 56 & 66.7 & 55.0 & 47.0 & 98.5 & 44.2 & 68.4 & 76.1 & 76.2 & 76.8 & 65.0 & 60.0 \\
\hline Qatar & 32 & 70.8 & 70.0 & 68.0 & 99.7 & 71.9 & 70.5 & 71.2 & 79.7 & 81.8 & 45.0 & 50.0 \\
\hline Saudi Arabia & 77 & 62.1 & 40.0 & 46.0 & 99.7 & 61.9 & 65.8 & 72.7 & 68.4 & 76.4 & 40.0 & 50.0 \\
\hline Singapore & 2 & 89.4 & 90.0 & 86.0 & 91.2 & 93.8 & 96.9 & 96.9 & 83.7 & 90.0 & 85.0 & 80.0 \\
\hline Tunisia & 107 & 57.7 & 40.0 & 41.0 & 74.3 & 70.8 & 81.2 & 69.1 & 74.8 & 61.2 & 35.0 & 30.0 \\
\hline
\end{tabular}




\begin{tabular}{ccccccccccccc}
\hline $\begin{array}{c}\text { United Arab } \\
\text { Emirates }\end{array}$ & 25 & 72.4 & 55.0 & 69.0 & 99.5 & 85.8 & 74.7 & 83.8 & 83.8 & 82.4 & 40.0 & 50.0 \\
$\quad$ United & 13 & 75.8 & 90.0 & 76.0 & 62.9 & 30.3 & 91.1 & 75.6 & 74.4 & 88.0 & 90.0 & 80.0 \\
$\quad$ Kingdom & & & & & & & & & & & & \\
United States & 12 & 76.2 & 80.0 & 73.0 & 66.2 & 51.8 & 88.8 & 98.5 & 76.6 & 87.0 & 70.0 & 70.0 \\
$\quad$ Yemen & 133 & 53.7 & 30.0 & 18.0 & 91.5 & 59.9 & 54.0 & 57.1 & 68.5 & 77.6 & 50.0 & 30.0 \\
\hline
\end{tabular}

\section{Appendix B}

\section{Extended Regional Aggregate Regression Results}

Table B1. Interest variable: Government effectiveness perception; Adjusted R-Squared $=73.2 \%$

\begin{tabular}{ccccccc}
\hline IndVA & Coef. & Std. Err. & $\mathbf{t}$ & $\mathbf{P}>\mathbf{t}$ & [95\% Conf. & Interval] \\
\hline FDI & $2.97 \mathrm{E}-10$ & $1.22 \mathrm{E}-10$ & 2.43 & 0.017 & $5.43 \mathrm{E}-11$ & $5.39 \mathrm{E}-10$ \\
GR & 0.202432 & 0.276591 & 0.73 & 0.466 & -0.3469822 & 0.7518471 \\
GCF & 0.11899 & 0.165189 & 0.72 & 0.473 & -0.2091377 & 0.4471181 \\
Trade & -0.2515 & 0.043562 & -5.77 & 0.000 & -0.3380264 & -0.1649662 \\
LP & 0.001759 & 0.000142 & 12.4 & 0.000 & 0.0014774 & 0.0020411 \\
Government Effectiveness & 0.252465 & 0.058707 & 4.3 & 0.000 & 0.13585 & 0.369079 \\
Constant & 10.54104 & 4.398901 & 2.4 & 0.019 & 1.803168 & 19.27892 \\
\hline
\end{tabular}

Table B2. Interest variable: Control of corruption; Adjusted R-Squared $=72.7 \%$

\begin{tabular}{ccccccc}
\hline IndVA & Coef. & Std. Err. & $\mathbf{t}$ & $\mathbf{P}>\mathbf{t}$ & [95\% Conf. & Interval] \\
\hline FDI & $2.89 \mathrm{E}-10$ & $1.23 \mathrm{E}-10$ & 2.36 & 0.020 & $4.57 \mathrm{E}-11$ & $5.33 \mathrm{E}-10$ \\
GR & 0.2046751 & 0.278436 & 0.74 & 0.464 & -0.3484047 & 0.757755 \\
GCF & 0.0827088 & 0.165388 & 0.5 & 0.618 & -0.2458136 & 0.411231 \\
Trade & -0.2362001 & 0.042078 & -5.61 & 0.000 & -0.3197836 & -0.15262 \\
LP & 0.001708 & 0.000144 & 11.84 & 0.000 & 0.0014215 & 0.001994 \\
Control of Corruption & 0.2310492 & 0.055737 & 4.15 & 0.000 & 0.1203348 & 0.341764 \\
Constant & 12.51077 & 4.324169 & 2.89 & 0.005 & 3.921342 & 21.10021 \\
\hline
\end{tabular}

Table B3. Interest variable: Law perception; Adjusted R-Squared $=74.5 \%$

\begin{tabular}{ccccccc}
\hline IndVA & Coef. & Std. Err. & $\mathbf{t}$ & $\mathbf{P}>\mathbf{t}$ & [95\% Conf. & Interval] \\
\hline FDI & $2.41 \mathrm{E}-10$ & $1.18 \mathrm{E}-10$ & 2.04 & 0.044 & $6.44 \mathrm{E}-12$ & $4.76 \mathrm{E}-10$ \\
GR & 0.1953408 & 0.268384 & 0.73 & 0.469 & -0.3377702 & 0.728452 \\
GCF & 0.2017705 & 0.162978 & 1.24 & 0.219 & -0.1219653 & 0.525506 \\
Trade & -0.2457661 & 0.039789 & -6.18 & 0.000 & -0.324802 & -0.16673 \\
LP & 0.0016041 & 0.000143 & 11.2 & 0.000 & 0.0013196 & 0.001889 \\
Perception of Law & 0.2929845 & 0.058766 & 4.99 & 0.000 & 0.1762533 & 0.409716 \\
Constant & 8.727032 & 4.345944 & 2.01 & 0.048 & 0.0943488 & 17.35972 \\
\hline
\end{tabular}

Table B4. Interest variable: Voice accountability perception; Adjusted R-Squared $=69.7 \%$

\begin{tabular}{ccccccc}
\hline IndVA & Coef. & Std. Err. & t & P>t & [95\% Conf. & Interval] \\
\hline FDI & $3.55 \mathrm{E}-10$ & $1.35 \mathrm{E}-10$ & 2.63 & 0.010 & $8.72 \mathrm{E}-11$ & $6.22 \mathrm{E}-10$ \\
GR & 0.1726332 & 0.293934 & 0.59 & 0.558 & -0.4112301 & 0.756496 \\
GCF & 0.0560898 & 0.173907 & 0.32 & 0.748 & -0.2893558 & 0.401535 \\
Trade & -0.2074419 & 0.046146 & -4.5 & 0.000 & -0.2991043 & -0.11578 \\
LP & 0.0020156 & 0.000171 & 11.77 & 0.000 & 0.0016753 & 0.002356 \\
Voice Accountability & 0.2566349 & 0.09995 & 2.57 & 0.012 & 0.0580962 & 0.455174 \\
Constant & 11.6389 & 4.760816 & 2.44 & 0.016 & 2.182126 & 21.09568 \\
\hline
\end{tabular}

\section{Copyrights}

Copyright for this article is retained by the author(s), with first publication rights granted to the journal.

This is an open-access article distributed under the terms and conditions of the Creative Commons Attribution license (http://creativecommons.org/licenses/by/4.0/). 